\title{
Sequence stratigraphy and evolution of a basin-slope succession: The Late Proterozoic Wonoka Formation, Flinders Ranges, South Australia
}

\author{
P. A. DiBONA, ${ }^{*}$ C. C. voN DER BORCH ${ }^{1}$ AND N. CHRISTIE-BLICK \\ ${ }^{1}$ School of Earth Sciences, Flinders University of South Australia, Bedford Park, SA 5042, Australia. \\ ${ }^{2}$ Lamont-Doherty Geological Observatory of Columbia University, Palisades, New York, \\ NY 10964, USA
}

\begin{abstract}
A shelf to basin-slope transition is vertically and laterally exposed within the Late Proterozoic Wonoka Formation in the northern Flinders Ranges of South Australia. The shelf to basin-slope transition can be divided into four units ( $\mathrm{C}$ to F) which are defined on the basis of facies, sedimentary structures, contacts, stratal geometry, and the type and abundance of down-slope mass movement. The lowest unit $(C)$ is mudstone dominated and parallel laminated with rare synsedimentary slides. Unit $D$, a thin, resedimented siliciclastic-carbonate unit deposited on a sequence boundary at the end of unit $C$ progradation, displays a lateral facies change from well bedded 'outer shelf' deposits in the east to basin-slope debris flows in the west. Unit $\mathrm{E}$ forms a shallowing and coarsening upward succession from 'outer shelf' siltstone to 'inner shelf' storm wave influenced sandstone deposits. The unit thickens westwards, in the interpreted down-slope direction, where it becomes finer grained and thinner bedded and displays an increasing abundance of synsedimentary slides. Unit $F$, deposited on an inferred shelf to basin-slope transition, coarsens and shallows upward, thickens to the west and contains the highest percentage of sandstone and synsedimentary slides. Unit $G$, deposited at shelf depths, also shallows and coarsens upward from a thin, basal carbonate-siliciclastic member, with sandstone increasing upsection to a gradational contact with the Pound Subgroup.

Three sequences can be defined within this transition on the basis of facies, stratal terminations, and facies discontinuities at inferred sequence boundaries. Each sequence is marked by a transgressive base, overlain by a shallowing-upward succession. On the inferred shelf and near the shelfbreak, toward the top of the succession, facies discontinuities at sequence boundaries are more obvious, with distinct contrasts in lithology and inferred palaeoenvironments; farther down-slope and stratigraphically lower in the succession, the boundaries are cryptic, and only lateral tracing of the contacts from the shelf to the slope or the observation of stratal terminations permits them to be recognized.
\end{abstract}

Key words: Adelaide Geosyncline, basin slope evolution, sequence stratigraphy, Wonoka Formation.

\section{INTRODUCTION}

The aim of this paper is to describe and interpret the facies and sequence stratigraphy of an outcropping shelf to basin-slope transition within the Late Proterozoic Wonoka Formation, northeastern Arkaroola Syncline, Adelaide Geosyncline, South Australia (Fig. 1). The locality studied here, in a region with prominent lateral facies changes (Coats \& Blissett 1971), contains large-scale parallel bedded to obliquely bedded units that can easily be recognized on aerial photographs and by field mapping. Outcrop permits identification of stratal terminations as well as specific lateral and vertical facies changes, some of which can be traced from interpreted shelf to slope regions. This allows both sequence interpretation, based on visible bedding terminations (the seismic-stratigraphic approach), and the mapping of facies discontinuities, together with the interpretation of palaeoenvironments and facies trends. The data can be interpreted in terms of a two-dimensional sequence stratigraphic and facies model, which involves three well defined depositional sequences. This in turn permits a consideration of the effects of relative sea level changes on slope evolution and the associated processes. The methodology and application of sequence stratigraphy to Proterozoic successions are summarized by Christie-Blick et al (1988) and von der Borch et al (1988). Sequence stratigraphic terminology used throughout this paper is after Haq et al (1987) and van Wagoner et al (1988).

*Present address: Department of Geology, WA Centre for Petroleum Exploration, Curtin University, GPO Box U1987, Perth, WA 6001, Australia. 

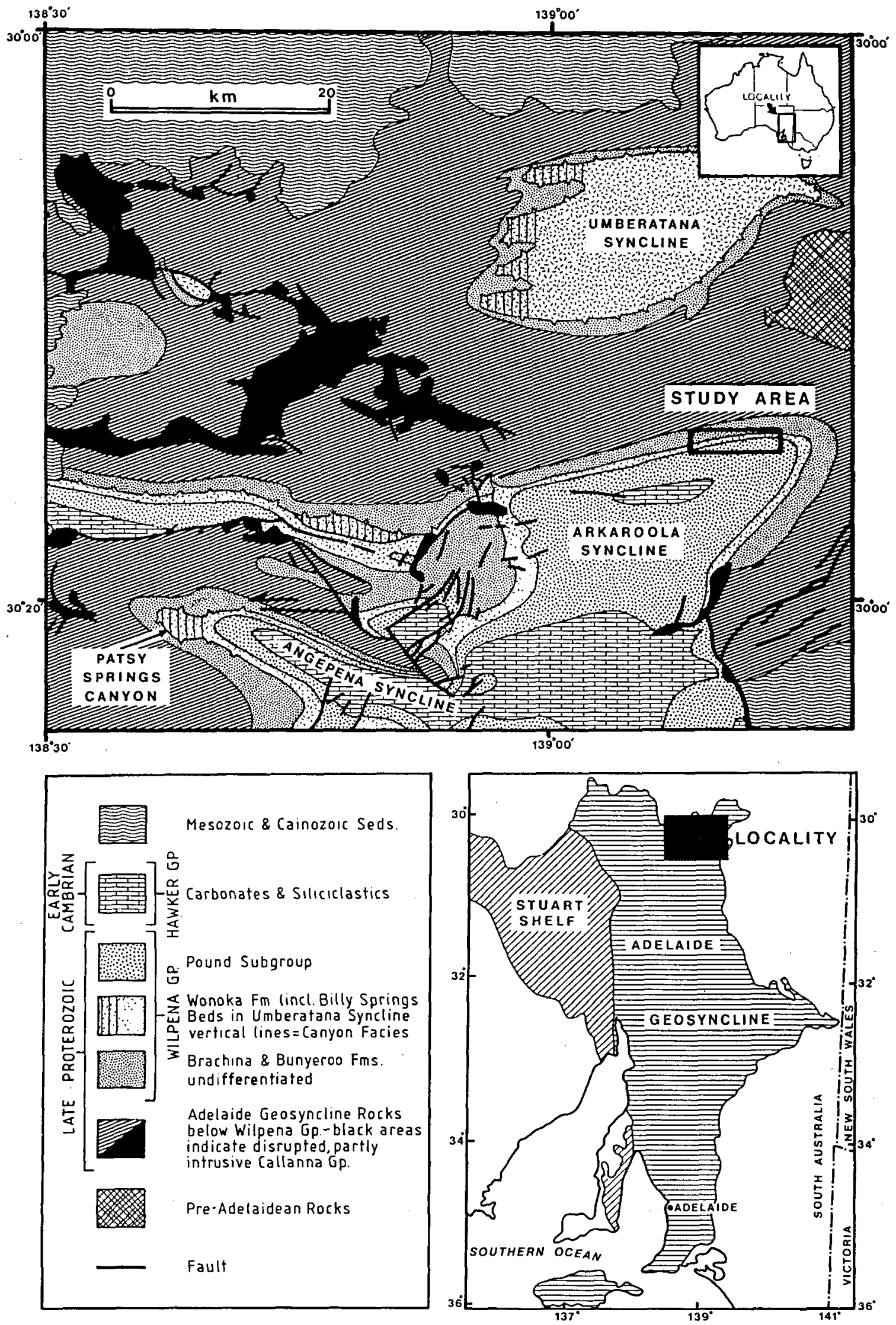


\section{REGIONAL SETTING}

The Late Proterozoic Wonoka Formation forms part of the Adelaide Geosyncline basin fill (Fig. 2). The Adelaide Geosyncline extends from the Flinders to the Mount Lofty Ranges (Fig. 1) and contains a thick succession of syn- to post-rift volcanics and sediments of mid-Proterozoic to Cambrian age (for a summary see Preiss 1987). The basin fill has been divided into three supergroups, which are bounded by unconformities and defined by their tectonic and palaeogeographic setting (Preiss 1987). The supergroups are the basal Warrina Supergroup, which includes the syn-rift Callana and Burra Groups; the Heysen Supergroup, containing the glacial and marine sediments of the Umberatana Group and the Late Proterozoic, post-glacial Wilpena Group; and the overlying Moralana Supergroup, which includes all Adelaide Geosyncline Cambrian deposits (Fig. 2).

The Wonoka Formation is stratigraphically located within the Wilpena Group, a unit that can be divided crudely into two major transgressive-regressive cycles (Fig. 2). The lower cycle includes the Nuccaleena Formation, Brachina Formation, and $\mathrm{ABC}$ Range Quartzite, whereas the upper cycle includes the Bunyeroo and Wonoka Formations and the overlying Pound Subgroup (Jenkins \& Gostin 1983; Preiss 1987; von der Borch

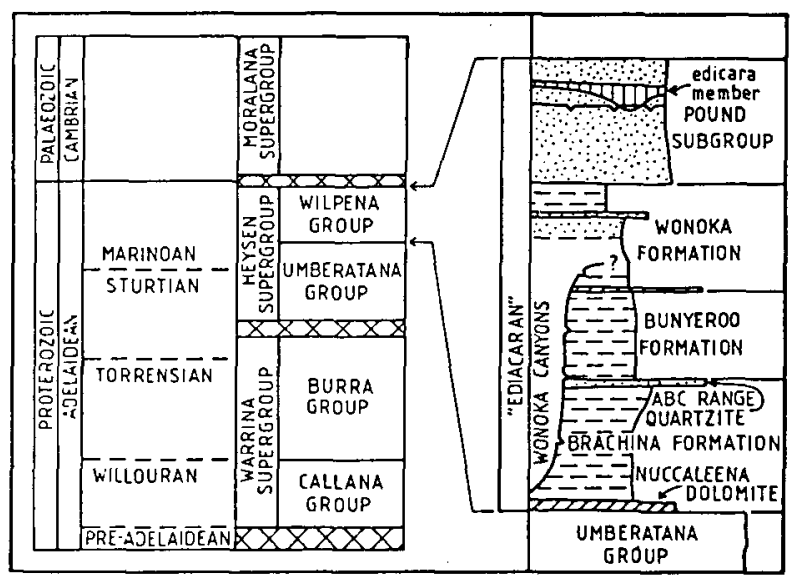

Fig. 2 Stratigraphic nomenclature and succession of the Adelaide Geosyncline basin fill and the Wilpena Group. Terminology and division of the supergroups is after Preiss (1987). et al 1988). In the central Flinders Ranges the Wonoka Formation is dominated by shelf sedimentation and generally shallows-up from outer-shelf siliciclastics and minor carbonates at the base to the overlying deltaic and continental facies of the Bonney Sandstone (Haines 1990). In the northern Flinders Ranges the Wonoka Formation is generally finer grained and thinner bedded than coeval facies developed in the central Flinders Ranges (DiBona \& von der Borch 1986). Largely on the basis of these facies changes and associated palaeocurrents, Haines (1990) argued that deposition of the Wonoka Formation took place mainly in a shelfal environment in the central Flinders Ranges and in relatively deep basinal settings in the north and southeast (see also Preiss 1987). However, shallow-water sediments that include tepee structures and cryptalgal laminites are present in the lower portion of the formation in the northern Flinders Ranges - associated with the development of a major unconformity (von der Borch et al 1988; DiBona 1989). Shallow-water facies within the lower Wonoka Formation and the possibly subaerially eroded canyons in the northern Flinders Ranges (Eickhoff et al 1988; von der Borch et al 1989) may suggest a more complex basin geography, particularly during early Wonoka time.

\section{UNITS OF THE WONOKA FORMATION, NORTHEAST ARKAROOLA SYNCLINE}

\section{Units $A$ and $B$}

At the base of the Wonoka Formation (as defined by Gostin \& Jenkins 1983) in the Arkaroola Syncline is a thin, regionally persistent dolostone (base of unit A, Figs 3, 4; unit 1 of Haines 1990). Above this dolostone are beds and lenses of calcareous sandstone with possible wave modified ripples and minor carbonate clast breccias overlain by parallel laminated siltstone and mudstone. The contact between units A and B is generally poorly exposed, but on the basis of the regional geology these units probably are separated by an unconformity (DiBona 1989).

Unit B is laterally extensive (Figs 3, 4; section 2) and consists of mudstone to very fine sandstone, and thin-bedded cross-laminated carbonates with

Fig. 1 Locality of Late Proterozoic Adelaide Geosyncline (lower right), location of the region investigated in the northcastern Arkaroola Syncline (Gammon Ranges National Park), and general geology of the northern Flinders Ranges. Adapted from 1:600 000 geological map compiled by Preiss (1983) and after von der Borch et al (1988, fig. 2). Wonoka Formation canyon facies differentiated by vertical lines, see text for details. 


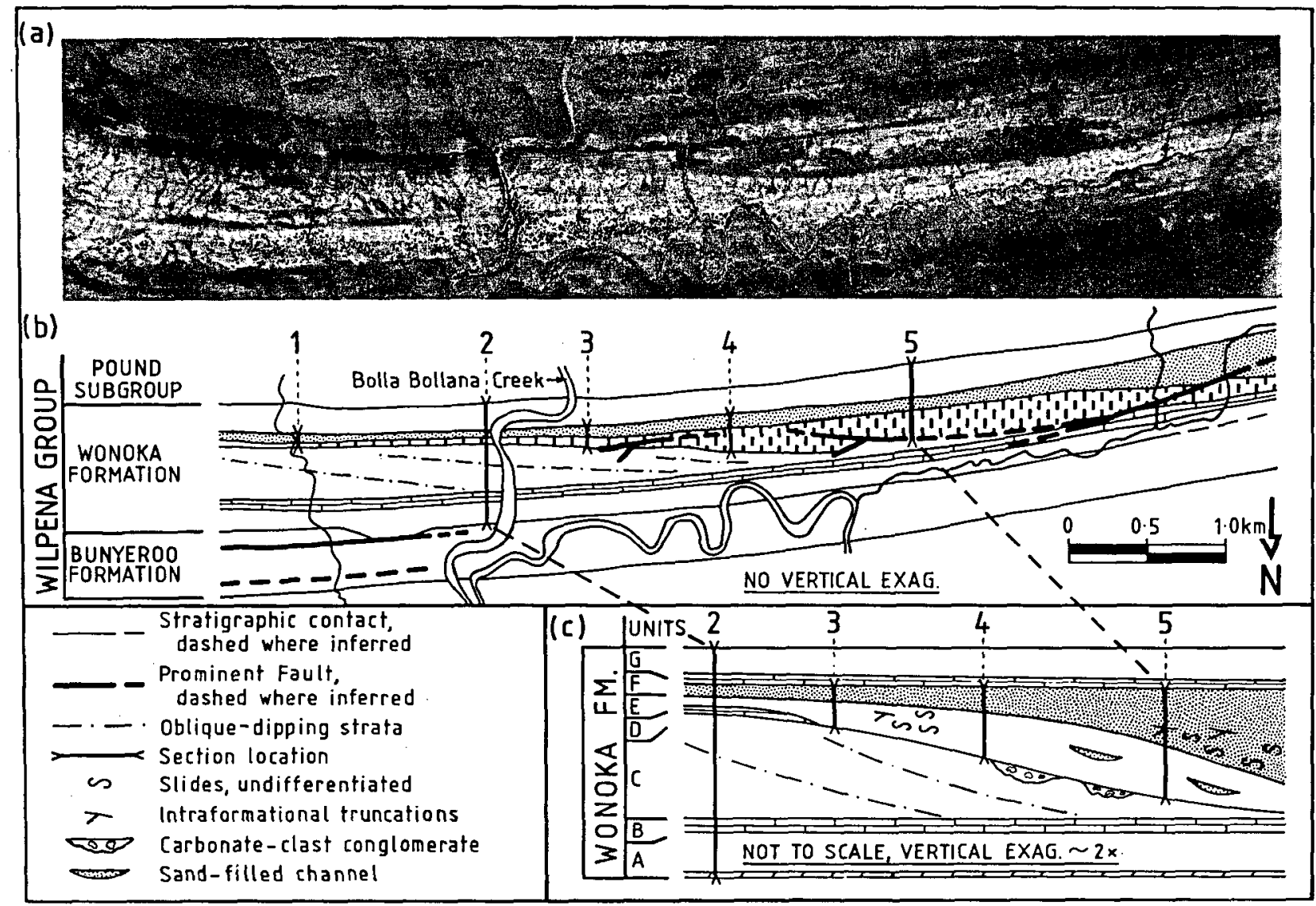

Fig. 3 Aerial photograph, geological map, and schematic cross-section of shelf to basin-slope transition within the Wonoka Formation, northeast Arkaroola Syncline. (a) Aerial photograph of study area. Department of Lands South Australia photograph, survey 2680, no. 44, scale 1:40000; used with permission. (b) Geological map of study area with localities of measured sections and major basin-slope units. Same scale as aerial photograph; note Bolla Bollana Creek for reference. (c) Schematic cross-section highlighting shelf to slope transition and the units defined within the Wonoka Formation. Note the inverted orientation of a-c.

mudstone-siltstone drapes. These lithologies form crude cycles (ca $300-800 \mathrm{~mm}$ ), with carbonate increasing upsection to a sharp contact with the basal siliciclastics of the next cycle.

\section{INTERPRETATION}

Units $A$ and $B$ were deposited on a shelf. The basal Wonoka Formation dolostone (base of unit A) is interpreted as a basin-wide marker horizon and condensed interval (von der Borch et al 1988). Upsection, the presence of interbedded sandstones and carbonates at this stratigraphic level is unique. A shelf setting is inferred on the basis of the carbonate clast breccias that may represent storm reworking, and possible wave modified sandstone lenses and channels.

Lithostratigraphic correlatives of unit B are present over a large area within the Wonoka
Formation (unit 3 of Haines 1990). To the south, near Angepena Syncline (Fig. 1), this lithofacies overlies supratidal facies of the lower Wonoka Formation and was likely deposited in a shallowshelf environment (DiBona \& von der Borch 1986). In the Arkaroola Syncline, the general lack of deep-water sediments, the lithological alternations, crude cyclicity, lateral facies associations and the regional extent of the unit may also suggest a relatively shallow-shelf setting.

\section{Unit C}

Unit $\mathrm{C}$ is mudstone dominated, with the proportion of siltstone increasing upsection at the expense of claystone (Fig. 4). The mudstones are calcareous and parallel laminated with thin, graded laminae throughout and occasional very thin $(10-30 \mathrm{~mm})$ featureless beds of fine grained carbonate. Siltier 


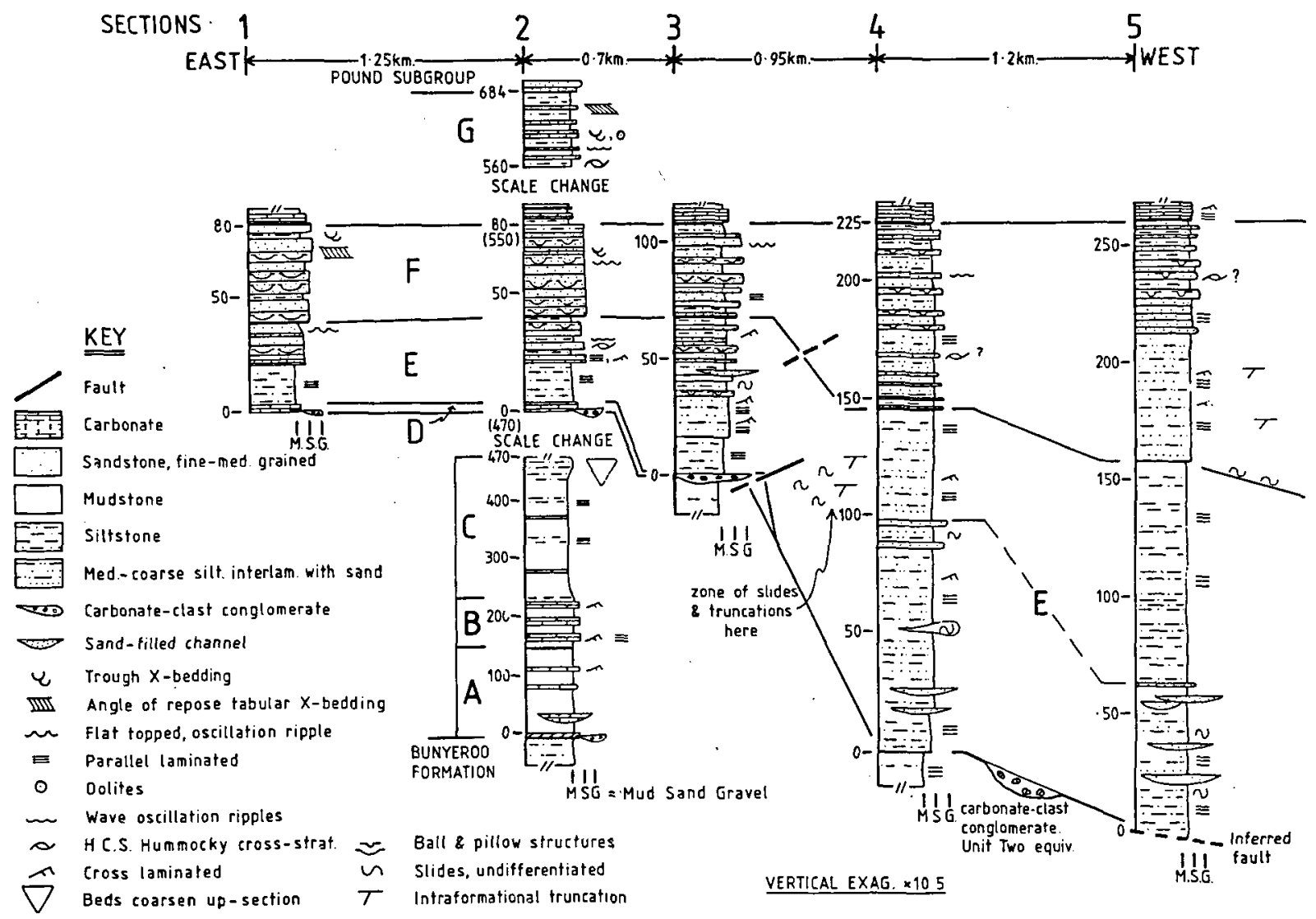

Fig. 4 Stratigraphic logs across the shelf to basin-slope transition within the Wonoka Formation. For section locations see Fig. 2. Note the scale changes within section 2 and the inverted east-west orientation in Figs 4-6.

horizons are present throughout the unit, with siltstone generally increasing toward the top (Fig. 4). Synsedimentary slides are rare.

East of sections 1 and 2 (Figs 3,4 ), unit $\mathrm{C}$ is the thickest of all units within the Wonoka Formation, but becomes thinner along strike to the west. The lower contact is gradational over $1-5 \mathrm{~m}$. Unit $\mathrm{C}$ is overlain with sharp contact by unit $\mathrm{D}$ (sections 1,2 , and 3; Fig. 4) and unit $E$ (section 4; Fig. 4). In section 5 the upper contact of Unit $C$ is faulted (Figs $3,4)$.

\section{INTERPRETATION}

Unit $C$ is the basal portion of a fine grained, prograding basin-slope.* The parallel-laminated and graded mudstones which dominate the unit are interpreted as low concentration turbidity current deposits. The occasional thin carbonate beds may

*Basin-slope, as opposed to a continental slope, is used to define a sedimentary slope within a restricted or small basin (Stow \& Piper 1984). represent deep-water hemipelagic deposition or, alternatively, may be diagenetic. The thickness, lateral extent, and deep-water facies within unit $\mathrm{C}$ are comparable with similar associations from both modern and ancient slopes (Doyle \& Pilkey 1979; Stow \& Piper 1984). The coarser facies (siltstone) at the top of the unit in sections 1 and 2 may represent an outer shelf deposit.

\section{Unit D}

Unit $\mathrm{D}$ consists of about $3 \mathrm{~m}$ of carbonate beds (commonly less than $30 \mathrm{~mm}$ thick). The beds are parallel laminated to cross-laminated and are interstratified with mudstone and siltstone. East of section 2 (Fig. 4), the unit has a uniform thickness and lithology, but between sections 2 and 3 (Figs 3, 4) the unit varies from 0.8 to $2 \mathrm{~m}$ in thickness and contains a high percentage of intraformational carbonate clasts. Farther west it is discontinuous and present only as conglomeratic or brecciated lenses (Figs 3,4). The lower contact with unit $C$ is sharp in section 2. A gradational contact over 
approximately $0.5 \mathrm{~m}$ occurs between unit $\mathrm{D}$ and overlying unit E siltstones in sections 1 and 2, and there is a sharp contact between unit $\mathrm{E}$ and unit $\mathrm{D}$ conglomerates in section 3 . Unit $D$ is absent in sections 4 and 5 (Fig. 4).

\section{INTERPRETATION}

On the basis of lithology, the lack of shallow water indicators and its reduced thickness and lateral persistence throughout the eastern Arkaroola Syncline, an outer-shelf setting is inferred for unit D. The upsection transition to outer shelf deposits and laterally to basin slope deposits also provides evidence for a deep water setting. Relatively thin, mixed siliciclastic and carbonate sequences can form in a variety of settings, for example on a shallow shelf or a tidal flat. However, unlike unit D, successions from these settings overall are thicker, contain distinct cycles, and have well defined shallow-water facies (Shinn 1983). The conglomeratic lenses within unit D probably were formed by downslope mass wasting following deposition of the unit close to or near a shelf-break (Fig. 5b).

There is a sharp lithological contrast between units $C$ and $D$. Carbonate is present in low amounts throughout unit $\mathrm{C}$, possibly because of dilution by siliciclastic input. On this basis, unit $D$ may represent a period of less dilution of the carbonate component. Deposition of unit $\mathrm{D}$ at the end of unit $C$ progradation, at a time of very low siliciclastic input, supports this interpretation.

\section{Unit E}

In sections 1,2 and 3 (Figs 3,4 ), the lower part of unit $E$ is composed of very thin $(10-30 \mathrm{~mm})$ parallel laminated beds that grade from siltstone to silty claystone or mudstone. In contrast, the upper portion of the unit is composed of fine to medium grained sandstones that are thin bedded to thick bedded (0.03-1 m), and interbedded with siltstone and mudstone. The sandstone beds contain possible hummocky cross-stratification, rare large ball-andpillow structures, and wave ripples.

West of section 2, unit $E$ thickens and changes facies (Figs 3, 4). Sand-filled channels are present in section 3 , along with a much higher percentage of very thin-bedded sandstone and siltstone (Fig. 4). Between sections 3 and 4 are numerous synsedimentary slides, less than $1 \mathrm{~m}$ in thickness, and rare intraformational truncations (Fig. 4). Farther west the unit is dominated by parallel laminated graded

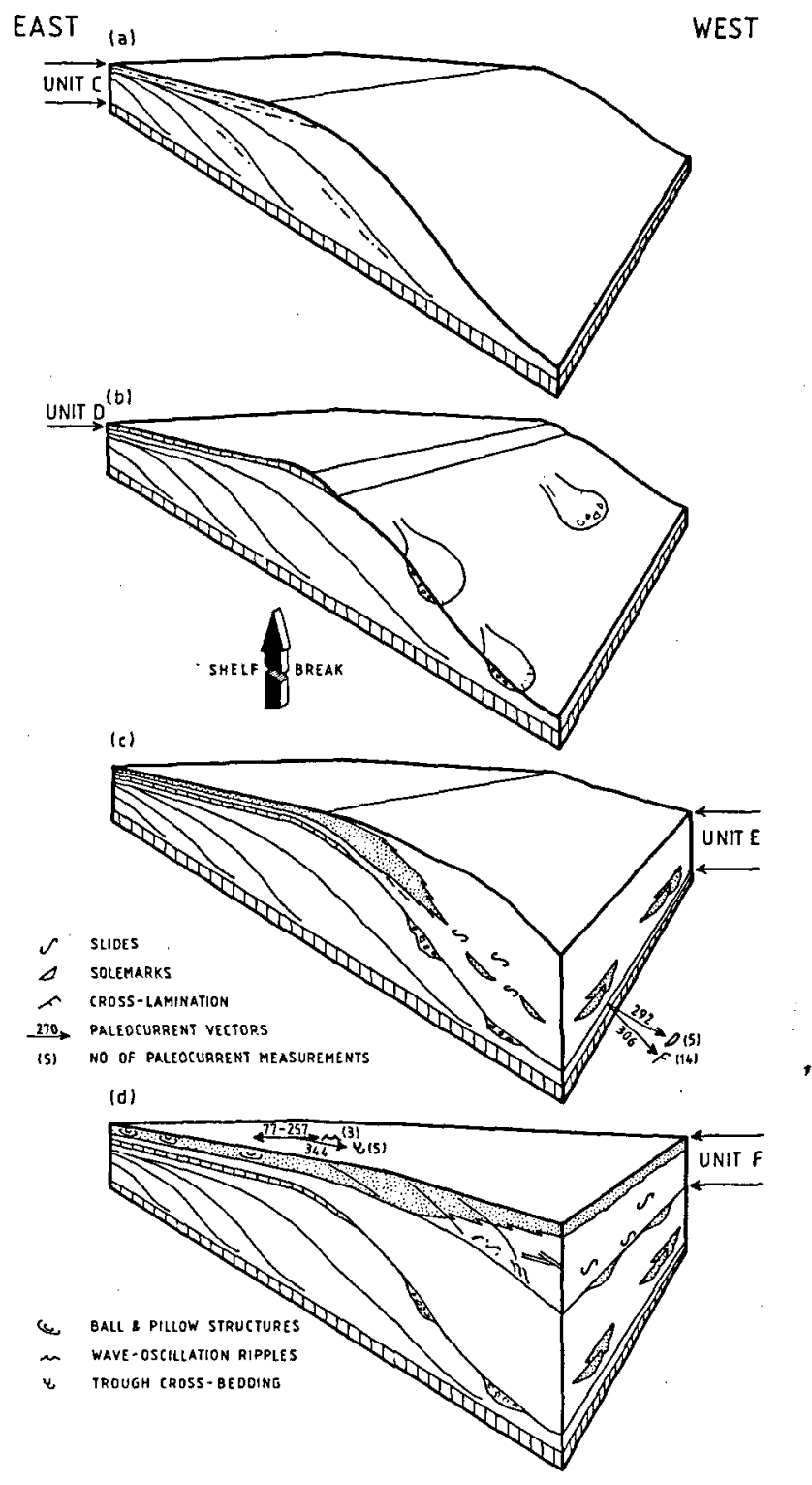

Fig. 5 Models for the evolution of the Wonoka Formation basin slope, northeast Arkaroola Syncline. (a) Progradation of unit $C$ with downlap on to unit B. Unit C coarsens upward with progradation ending prior to the deposition of unit $D$. (b) Deposition of unit $D$ on the shelf and down the slope as line-source conglomeratic lenses; base of sequence 3. (c) Unit E shallows-upward from outer to inner shelf deposits with deposition on the slope as fine-grained turbidites with synsedimentary slides and sand channels. (d) Deposition of unit F took place as a major sand 'pulse' on the shelf and to the west as fine grained turbidites shallowing to storm dominated shelf deposition, sequence 4 .

siltstone and mudstone with a sandstone dominated member that consists of broad, low channels and occasional synsedimentary slides. The channels are filled with parallel laminated, fine grained sandstone to siltstone with occasional 
cross-lamination and sole marks. Palaeocurrents, measured from both cross-laminations and flute marks and corrected for tectonic tilt, are directed toward the northwest (Fig. 5c).

The lower contact between unit $\mathrm{E}$ and underlying units in sections 1 and 2 is gradational. In other sections there is a sharp lower contact either on unit $\mathrm{D}$ conglomerates or directly on unit $\mathrm{C}$. The upper contact in all sections is sharp, beneath sandstone or siltstone of unit $F$.

\section{INTERPRETATION}

In sections 1,2 , and 3 a vertical transition from a fine grained, outer shelf setting to a current and wave influenced shelf is inferred for unit $E$. This transition suggests a shallowing-upward progradational sequence. The lower siltstones and mudstones lack any evidence for deposition above wave base, contain no coarse grained sediments or synsedimentary slides, and grade laterally into basin slope sediments. The sand rich upper portion was deposited under wave and current influence on the basis of wave ripples, hummocky cross-stratification, and lateral facies changes. Ball-and-pillow structures suggest rapid deposition for some of the sandstone beds and are associated with storm dominated shelf settings (Mount 1982).

West of section 3 (Fig. 4), deposition on a prograding slope is indicated by the association of fine grained turbidites and by an increase in synsedimentary slides. The slides are concentrated between sections 3 and 4 , which may indicate the position of a shelf break. The palaeocurrent data support northwestward progradation of this unit.

\section{Unit F}

In sections 1, 2, and 3 (Fig. 4) unit $F$ is dominated by thick to very thick bedded $(0.3->1 \mathrm{~m})$ relatively mature sandstones. Up to $80 \%$ of beds within unit $F$ contain ball-and-pillow structures which reach a maximum of $2 \mathrm{~m}$ in diameter. In sections 1 and 2, sedimentary structures include hummocky crossstratification, current and wave ripples, and trough cross-bedding. Corrected palaeocurrent directions from unidirectional trough cross beds are directed towards $344^{\circ}$, and wave ripple crests are oriented to the northeast-southwest, almost at right angles to the palaeocurrents (Fig. 5d).

West of section 3 (Fig. 4), unit $F$ becomes finer grained and thinner bedded. In section 5 the unit is dominated by graded beds of parallel laminated very fine to fine grained sandstone to siltstone.
Upsection, there is an increase in thin to medium bedded sandstone with occasional wave ripples, hummocky cross-stratification, and ball-and-pillow structures. The unit has the highest percentage of synsedimentary slides, mainly in the form of coherent soft-sediment fold sheets and intraformational truncations (Fig. 5d). However, these are present only west of sections 4 and 5 (Figs 3 and 4).

The lower contact with unit $\mathrm{E}$ is sharp. In sections 1 and 2 there is an apparent disconformity at the disruption of unit $\mathrm{E}$ by ball-and-pillow structures (Fig. 4). To the west the lower contact is marked by a distinct increase in grain size and a concentration of synsedimentary slides. Farther west, narrow channels are filled with unit $F$ sediments at the contact (Figs 3,4). The upper contact with unit $G$ is sharp.

\section{INTERPRETATION}

Unit $\mathrm{F}$ was deposited by a high influx of sand on to a storm-wave dominated shelf that graded laterally into a basin-slope. In sections 1,2 , and 3 , the upward gradation from hummocky cross-stratification to angle-of-repose cross-bedding is consistent with a shallowing-upwards shelf succession (Johnson \& Baldwin 1986). Palaeocurrents from the trough cross-beds, together with their orthogonal relationship with wave ripple crests, may indicate offshore directed migration of lunate megaripples. This setting is inferred from the progradation of units $C, D$, and $E$ and facies changes within unit $F$ towards the west (Fig. 5d). Megaripple migration normal or oblique to the shoreline and offshore directed can be caused by rip currents, storm-surge ebb currents, or wind forced currents (Swift \& Niedoroda 1985; Walker 1985). Although longshore currents are common on modern shelves, offshore-directed sand transport is present both on modern shelves (Swift \& Niedoroda 1985) and in geological analogues (Leithold \& Bourgeois 1984; Walker 1985).

West of section 3, unit $F$ was deposited on a basin slope that shallowed upward during progradation to a storm dominated shelf. Basin-slope deposition is inferred from the presence of fine grained turbidites, unit thickening, and the high percentage of synsedimentary slides.

\section{Unit G}

There is a sharp contact between unit $F$ and a basal succession of unit $\mathrm{G}$ that includes a thin interval of 
siltstone and minor coarse grained sandstone laminae. Upsection, there is a thin $(\mathrm{ca} 10 \mathrm{~m})$ resedimented carbonate and siliciclastic member (Fig. 4), and farther upsection unit G coarsens upward into thin to medium bedded (30-300 mm) sandstones with wave ripples and hummocky crossstratification. A thin carbonate member with trough cross-bedding and possible recrystallized ooids is present between approximately $630 \mathrm{~m}$ and $640 \mathrm{~m}$ in section 2 (Fig. 4). From this level, medium bedded sandstones with angle-of-repose crossbedding increase upsection to the Pound Subgroup - Wonoka Formation contact (Fig. 4).

\section{INTERPRETATION}

A shallowing-upward succession from outer to inner shelf environments is interpreted for the transition within unit $G$. The carbonate member near the base is lithologically similar to unit $D$, and was also deposited at the end of a major siliciclastic depositional period on a relatively deep-water shelf. Upsection, the increase in sandstone, occurrence of wave and current reworking, and the presence of shallow-water carbonates (oolitic) all suggest a shallowing-upward succession to the Pound Subgroup.

\section{STRATAL GEOMETRY}

The origin of the stratal geometry observed at this locality (Fig. 3), whether sedimentary or structural, is critical to a sequence stratigraphy model based partly on stratal terminations and facies discontinuities. However, the distinction between sedimentary geometry and structural geometry cannot always be directly assessed because of poor outcrop, recent slope creep of the fine grained lithologies and the subtle nature of the often layer-parallel faults.

\section{Unit C}

The apparent 'clinoforms' within unit C (Fig. 3) are formed by resistant siltstone beds. They extend from near the top of unit $C$ to the base where they appear to downlap on to unit B, through a stratigraphic thickness of approximately $230 \mathrm{~m}$ (Fig. 3). The uncorrected dip of the clinoforms is $4-5^{\circ}$ between sections 3 and 4 but may be as high as $8^{\circ}$ east of the study area (Fig. 3). The primary dips inferred for the clinoforms are extremely high and unrealistic in terms of depositional slope angles. In addition, the values measured directly (i.e. $4-8^{\circ}$ ) represent minimum values without correcting for sediment compaction and true progradation direction.

On the basis of these high values, two possible interpretations for the 'clinoforms' in unit $\mathrm{C}$ are proposed: (1) they were formed purely by structural deformation of unit $\mathrm{C}$; or (2) they are primary sedimentary clinoforms that originally outlined the progradation of the basin slope but subsequently have been overprinted by structural deformation. Because of this uncertainty, the presence of these 'clinoforms' cannot be used to substantiate a basin slope interpretation for unit C. However, on the basis of characteristics that include facies, vertical and lateral variations and thickness, a prograding basin slope interpretation is considered to be the most plausible.

\section{Units $D$, E, and F}

Units $E$ and $F$ both thicken west of section 2 (Figs 3, 4 ), whereas unit D crops out only intermittently west of section 2 as conglomerate or breccia lenses. Both east and west of section 5 the contact between units $\mathrm{C}$ and $\mathrm{E}$ is faulted, and there is other faulting between sections 3 and 4 (Fig. 3). Clinoforms have not been observed in unit $\mathrm{E}$.

A single fault has been mapped near the contact between units $E$ and $F$ between sections 3 and 4 (Fig. 3) but between sections 4 and 5 outcrop is poor and faulting may be present. Poorly developed clinoforms, identified on enlarged aerial photographs, extend from near the top of unit $F$ and appear to terminate near the unit $E$ - unit $F$ contact.

The stratal geometry of units $\mathrm{E}$ and $\mathrm{F}$ is best interpreted as sedimentary in origin with some structural overprinting. The mapped fault in the vicinity of section 5 clearly has altered the geometry of units $C$ and $E$, but does not appear to continue along the entire contact between the two units. This is indicated by the distinct downslope facies of unit $D$ along parts of the contact. Sedimentological data from units $E$ and $F$, including downslope facies changes, concentration of synsedimentary slides near or at a shelfbreak (Fig. 4) and palaeocurrents all support a proposed sedimentary slope stratal geometry.

\section{SEQUENCE STRATIGRAPHY AND SLOPE EVOLUTION: DISCUSSION AND SIGNIFICANCE}

The Wonoka Formation shelf to basin-slope transition exposed in the Arkaroola Syncline has 

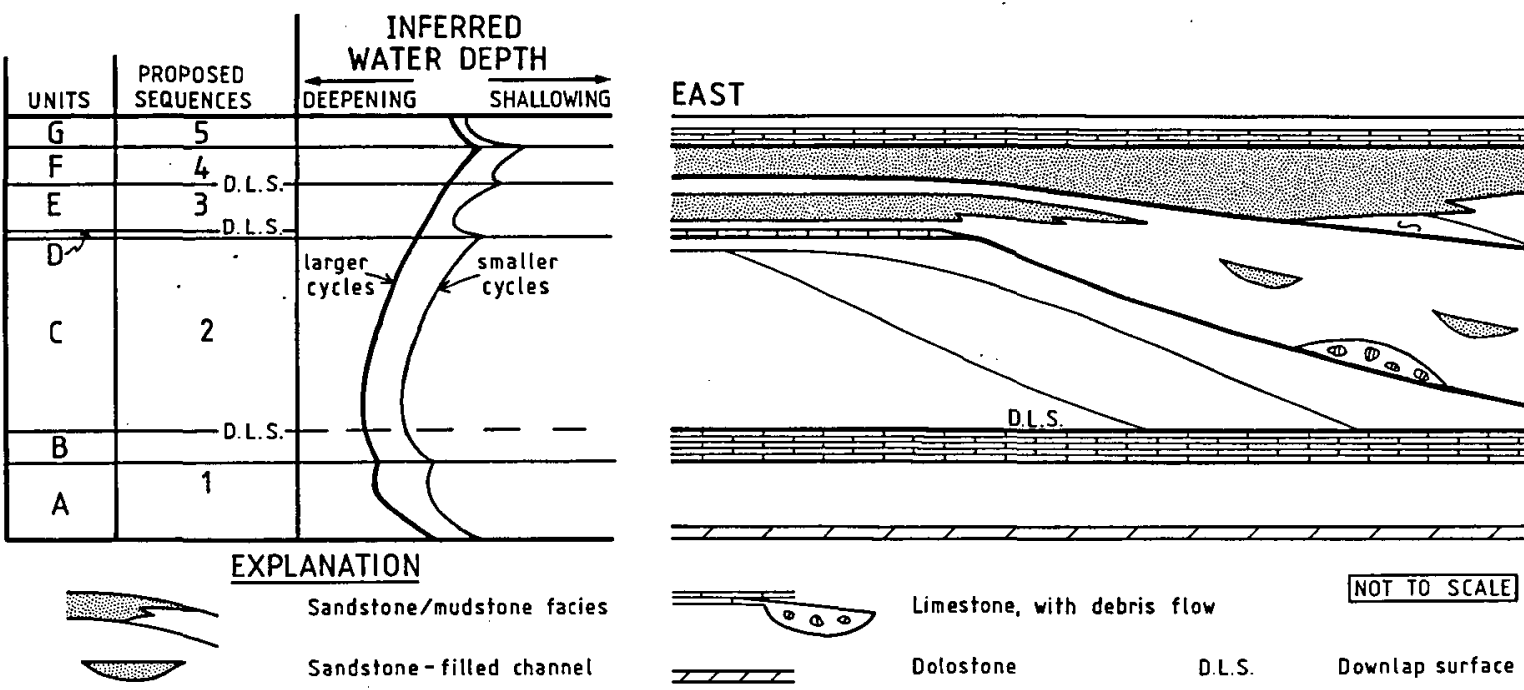

Fig. 6 Schematic cross-section and curves outlining the sequence stratigraphy and location of sequence boundaries in relation to the shelf to slope succession. Water depth inferred from sedimentary structures and stratigraphic/ palaeogeographic position of units (see text for detail).

evolved as a series of prograding depositional sequences (Figs 5, 6). These sequences can be identified by facies trends which typically are shallowing-upward, contacts bounded by marineflooding surfaces, and stratal terminations such as downlap surfaces (Figs 5, 6).

Sequence 2 represents one distinct deepeningshallowing cycle (Fig. 6). A transgression at the base of this sequence, which included the shelf carbonates of unit $B$, was followed by the inferred northwestward progradation of unit $C$ (Figs $3,5,6)$. As interpreted here a sequence boundary occurs at the base of unit $B$ with a downlap surface at the unit B-C contact, a surface of maximum transgression within sequence 2 (Fig. 6). In support of this model is the gradational transition from unit $B$ to $C$, the shallowing-upward succession within unit $C$, and the probable unconformity between units $A$ and $\mathrm{B}$.

Both sequences 3 and 4 are represented by progradational shallowing-upward successions, bounded by marine-flooding surfaces (Figs 5,6 ). At the base of sequence 3 is an interval (unit D) interpreted as condensed and possibly formed by relative sea level control rather than localized effects. This is suggested on the basis of its lateral extent, lithological contrast with the siliciclastic dominated succession below, location at the end of unit $\mathrm{C}$ sedimentation, environmental setting and its position at the base of a shallowing-upward succession.

Sequence 4 (unit F) is distinguished by a high influx of sand and an apparently shallower depositional environment. These reflect its position at the top of a larger, relative sea-level cycle within the Wonoka Formation (Fig. 6). The upper contact, a marine-flooding surface, is marked by the lithological change to basal unit $\mathrm{G}$ carbonates and siliciclastics at the base of sequence 5 .

The downlap surface within sequence 2 (Fig. 6) separates shelf (unit B) from deep-water/slope deposits (unit $C$ ) and the overlying shallowingupward succession. This contact and facies transition is widespread and can be recognized throughout the northern Flinders Ranges. Two other boundaries of regional significance are the basal condensed section of sequence 3 , unit $D$, inferred to be correlative with Haines' (1990) laterally extensive unit 8 marker horizon; and the sequence $4-5$ boundary which also is inferred to represent a 'drowning' event that juxtaposes unrelated depositional packages. However, sequences 3 and 4 are not recognized as distinct depositional sequences regionally; they are apparently correlative with a laterally extensive sandstone succession, informally named the 'upper Wonoka quartzite' (DiBona \& von der Borch 1986).

\section{CONCLUSIONS}

A transition from a shelf to a prograding basin-slope depositional system, divisible into a series of lithological units and depositional sequences, is exposed within the Late Proterozoic Wonoka Formation in the northeast Arkaroola Syncline. Unit $\mathrm{C}$ represents a progradational basin-slope 
system that shallows upwards to outer shelf depths. Units $D, E$, and $F$ were deposited across the palaeoshelf, above unit $C$, and prograded over the existing basin-slope to the northwest. The palaeoshelf deposits, in contrast to the basin-slope deposits, are characterized by coarser grain sizes, thicker bedded facies, a variety of wave-current sedimentary structures and stratigraphically thinner units. The basin-slope deposits, on the other hand, are characterized by fine grained turbidites, evidence of down-slope mass movement and a marked stratigraphic thickening of units.

The Wonoka Formation shelf to basin-slope transition can be divided into a series of depositional sequences. Sequences are identified on the basis of: (1) facies discontinuities at sequence boundaries, usually marine-flooding surfaces; (2) internal facies trends and associations; and (3) oblique terminations of stratal surfaces observed on aerial photographs. Each sequence is marked by a basal transgression and an upward-shallowing succession. The overall type and makeup of the sequences and their boundaries is dependent upon their location, both in relation to the shelfbasin-slope transition and to larger sea level cycles. On the inferred shelf and near the shelf break, facies discontinuities at sequence boundaries are distinct because marine flooding surfaces superimpose markedly contrasting facies (e.g. units F, G). Farther down-slope (deeper water) and stratigraphically lower, the boundaries are cryptic. Here boundaries are recognized by subtle grain size increases, tracing of contacts from the shelf and shelf break and the location of stratal terminations.

This study demonstrates the existence of depositional sequences within the Wonoka Formation and the application of sequence stratigraphy to outcropping Late Proterozoic sediments. In addition, the sequence model proposed here demonstrates both the hierarchy and stacking of depositional sequences within a single prograding basin-slope system.

\section{ACKNOWLEDGEMENTS}

Many co-workers are thanked for their direct and indirect input into this study, particularly A.E. Grady, K. Eickhoff, J. Clarke, P. Haines. DiBona especially thanks A. E. Grady for general advice and help in mapping problems and F. Chamalaun for help with sediment compaction problems. K. A. Plumb and W. V. Preiss are thanked for their helpful review and suggestions to the manuscript.

Esso Australia Ltd, the Australian Research Grants Scheme, and the Flinders University
Research Budget supported fieldwork by von der Borch and DiBona. This study was initiated as part of research toward a PhD degree by DiBona and supported by a research scholarship from Esso Australia Ltd. Travel to Australia by Christie-Blick was supported in part by the donors of the Petroleum Research Fund, administered by the American Chemical Society (PRF 16042-G2 to N.C-B.) and by Lamont-Doherty Geological Observatory.

Access to the Gammon Ranges National Park to conduct scientific research was made possible by the National Parks and Wildlife service.

\section{REFERENCES}

Christie-Blick N., Grotzinger J. P. \& von der BorCh C. C. 1988. Sequence stratigraphy in Proterozoic successions. Geology 16, 100-104.

CoAts R. P. \& Blissett A. H. 1971. Regional and economic geology of the Mount Painter Province. Department of Mines, Geological Survey of South Australia Bulletin 43, 426.

DiBona P. A. 1989. Geologic history and sequence stratigraphy of the Late Proterozoic Wonoka Formation, northern Flinders Ranges, South Australia. Ph.D. thesis, Flinders University of South Australia (unpubl.).

DiBONA P. A. \& VON DER BORCH C. C. 1986. Wonoka Formation sedimentation, relative sealevel, and basin analysis in the northern Flinders Ranges, South Australia. Eighth Australian Geological Convention, Adelaide, 1986. Geological Society of Australia, Abstracts 15.

Doyle L. J. \& Pilkey O. H. 1979. Geology of Continental Slopes. Society of Economic Paleontologists and Mineralogists, Special Publication 27.

EICKHOFF K. H., voN DER BorCh C. C. \& GRadY A. E. 1988. Proterozoic canyons of the Flinders Ranges (South Australia): Submarine canyons or drowned river valleys? In Jackson J. M. ed. Aspects of Proterozoic Sedimentary Geology. Sedimentary Geology 58, 21 7-235.

Goodwin P. W. \& ANDerson E. J. 1985. Punctuated aggradational cycles: A general hypothesis of episodic stratigraphic accumulation. Journal of Geology 93, 515-533.

Gostin V. A. \& Jenkins R. F. 1983. Sedimentation of the early Ediacaran, Flinders Ranges, South Australia. Geological Society of Australia, Abstracts 9, 196-197.

Haines P. W. (1990). A Late Proterozoic storm-dominated carbonate shelf sequence: The Wonoka Formation in the central and southern Flinders Ranges, South Australia. In Jago J. B. and Moore P. S. eds. The evolution of a Late Precambrian-Early Paleozoic rift complex: Adelaide Geosyncline. Geological Society of Australia, Special Publication 16, 177-198.

HaQ B. V., Hardenbol J. \& Vail P. R. 1987. Chronology of fluctuating sea levels since the Triassic (250 million years ago to present). Science 235, 1156-1167.

JENKINS R. F. \& Gostin V. A. 1983. Marinoan and Ediacaran type sections in the context of tectonic cycles in the Adelaide Geosyncline. Geological Society of Australia, Abstracts 10, 39-44.

Johnson H. D. \& BaLdwin C. T. 1986. Shallow siliciclastic seas. 
In Reading H. G. ed. Sedimentary Environments and Facies, 2nd edn, pp. 229-282. Elsevier, New York.

Leithold E. L. \& Bourgeols J. 1984. Characteristics of coarse-grained sequences deposited in nearshore, wavedominated environments: examples from the Miocene of southwest Oregon. Sedimentology 31, 749-775.

MouNT J. R. 1982. Storm-surge-ebb origin of hummocky cross-stratified units of the Andress Mountain member, Campito Formation (Lower Cambrian), White-Inyo Mountains, eastern California. Journal of Sedimentary Petrology 52, 941-950.

MOUNT J. R. \& WARD P. 1986. Origin of limestone/marl alterations in the upper Maastrichtian of Zumaya, Spain. Journal of Sedimentary Petrology 56, 228-236.

Preiss W. V. 1983. Adelaide Geosyncline and Stuart Shelf: Precambrian and Palaeozoic geology. 1:600,000 scale geological map, Department of Mines and Energy, Adelaide.

Preiss W. V. (CompiLer) 1987. The Adelaide Geosyncline: Late Proterozoic stratigraphy, sedimentation, palaeontology and tectonics. Geological Survey of South Australia, Bulletin 53.

Shinn E. A. 1983. Tidal Flat Environment. In Scholle P. A., Bebout D. G. and Moore C. H. eds. Carbonate depositional environments. American Association of Petroleum Geologists Memoir 33, 172-210.

Stow D. A. V. \& Piper D. J. W. eds. 1984. Fine-grained sediments: Deep-water processes and facies. Geological Society of London, Special Publication 15.
Swift D. J. P. \& Niedoroda A. W. 1985. Fluid and sediment dynamics on continental shelves. In Tillman R. W., Swift D. J. P. and Walker R. G. eds. Shelf sands and sandstone reservoirs. Society of Economic Paleontologists and Mineralogists, Short Course Notes 13, 47-133.

VAN Wagoner J. C., Posamentier M. W., Mitchum R. M. et al 1988. An overview of the fundamentals of sequence stratigraphy and key definitions. In Wilgus C. K. ed. Sealevel changes - an integrated approach. Society of Economic Paleontologists and Mineralogists, Special Publication 42, 39-45.

Von der Borch C. C., Christie-Blick N. \& Grady A. E. 1988. Concepts of seismic stratigraphic analysis applied to Upper Proterozoic Wilpena Group, Adelaide Geosyncline, South Australia. Australian Journal of Earth Sciences 35, 59-71, Von Der Borch C. C., Grady A. E., EICKhoff K. H. \& DiBona P. 1989. Late Proterozoic Patsy Springs canyon, Adelaide Geosyncline: Submarine or subaerial origin? Sedimentology 36, 777-792.

WALKER R. G. 1985. Geological evidence for storm transportation and deposition on ancient shelves. In Tillman R. W., Swift D. J. R. and Walker R. G. eds. Shelf sands and sandstone reservoirs. Society of Economic Paleontologists and Mineralogists, Short Course Notes 13, 243-302.

(Received 3 February 1988; accepted 21 September 1989) 